УдК 616.314-039.71-02:613.84

DOI 10.11603/2311-9624.2017.1.7698

\author{
(С). Я. Лаврін, В. В. Щерба, І. Я. Криницька
}

ДВНЗ «Тернопільський державний медичний університет імені І. Я. Горбачевського»

\title{
Стоматологічний статус осіб, схильних до регулярного активного куріння
}

Резюме. 3 курінням пов’язують істотне підвищення ризику ряду захворювань органів і тканин порожнини рота, перш за все патології пародонта та онкологічних новоутворень порожнини рота. Мета дослідження - вивчити поширеність, структуру та особливості клінічного перебігу захворювань тканин пародонта в осіб, схильних до регулярного активного куріння.

Матеріали і методи. Проведено дослідження 120 відвідувачів, які проходили профілактичні огляди в поліклініці Збаразької центральної районної комунальної лікарні, схильних до регулярного активного куріння. Для оцінки ступеня запального процесу в пародонті використовували папілярномаргінально-альвеолярний індекс, пародонтальний індекс, індекс Гріна-Вермільйона.

Результати досліджень та їх обговорення. Стоматологічне обстеження осіб, схильних до регулярного активного куріння, виявило захворювання пародонта у 102 осіб (85,0 \%), інтактний пародонт у 18 (15,0 \%). Разом $з$ тим, обстеження 30 осіб контрольної групи виявило захворювання пародонта у 12 осіб (40,0%), клінічно здорові тканини пародонта - в 18 осіб (60,0%). У осіб, схильних до регулярного активного куріння, середні значення індексу РМА трактувались як гінгівіт тяжкого ступеня та достовірно перевищували аналогічні дані групи контролю у 2,5 раза. Середні цифрові значення пародонтального індексу в осіб, схильних до регулярного активного куріння, відповідали пародонтиту середнього ступеня та достовірно перевищували аналогічні дані групи контролю у 4 рази. Стан гігієни ротової порожнини у 62 \% осіб, схильних до регулярного активного куріння, відповідав поганому гігієнічному стану, в 7 \% - дуже поганому, 22 \% - задовільному, 9 \% - доброму. Середні значення індексу Гріна-Вермільйона у курців достовірно перевищували аналогічні дані групи контролю у 3,1 раза. Висновки. Куріння сприяє збільшенню дифузних захворювань пародонта та поглибленню патологічного процесу.

Ключові слова: пародонт; куріння; гігієнічний стан; ротова порожнина.

\section{(С). Я. Лаврин, В. В. Щерба, И. Я. Криницкая}

ГВУз «Тернопольский государственный медицинский университет имени И. Я. Горбачевского»

\section{Стоматологический статус лиц, склонных к регулярному активному курению}

Резюме. С курением связывают существенное повышение риска ряда заболеваний органов и тканей полости рта, прежде всего патологии пародонта и онкологических новообразований полости рта. Цель исследования - изучить распространенность, структуру и особенности клинического течения заболеваний тканей пародонта у лиц, склонных к регулярному активному курению.

Материалы и методы. Проведено исследование 120 посетителей, которые проходили профилактические осмотры в поликлинике Збаражской центральной районной коммунальной больницы, склонных к регулярному активному курению. Для оценки степени воспалительного процесса в пародонте использовали папиллярно-маргинально-альвеолярный индекс, пародонтальный индекс, индекс Грина-Вермильйона.

Результаты исследований и их обсуждения. Стоматологическое обследование лиц, склонных к регулярному активному курению, выявило заболевания пародонта у 102 человек (85,0 \%), интактный пародонт - у 18 (15,0 \%). В то же время, обследования 30 человек контрольной группы выявило заболевания пародонта у 12 человек (40,0 \%), клинически здоровые ткани пародонта - в 18 (60,0 \%). У лиц, склонных к регулярному активному курению, средние значения индекса РМА трактовались как гингивит тяжелой степени и достоверно превышали аналогичные данные группы контроля в 2,5 раза. Средние цифровые значения пародонтального индекса лиц, склонных к регулярному актив- 
ному курению, соотносились с пародонтитом средней степени и достоверно превышали аналогичные данные группы контроля в 4 раза. Состояние гигиены полости рта у 62 \% лиц, склонных к регулярному активному курению, отвечали плохому гигиеническому состоянию, в 7 \% - очень плохому, $22 \%$ - удовлетворительному, 9 \% - хорошему. Средние значения индекса Грина-Вермильйона у курильщиков достоверно превышали аналогичные данные группы контроля в 3,1 раза.

Выводы. Курение способствует увеличению диффузных заболеваний пародонта и углублению патологического процесса.

Ключевые слова: пародонт; курение; гигиеническое состояние; полость рта.

\section{(c). Ya. Lavrin, V. V. Shcherba, I. Ya. Krynytska}

I. Horbachevsky Ternopil State Medical University

\section{Dental status of persons prone to regular active smoking}

Summary. Smoking is associated with significantly increased risk of diseases of organs and tissues of the oral cavity, especially periodontal pathology and cancer of the mouth.

The aim of the study - to investigate the prevalence, structure and clinical course of periodontal tissue diseases in people prone to regular active smoking.

Materials and Methods. A study of 120 visitors who had undergone preventive examinations in the Clinic of Zbarazh Central District Municipal Hospital exposed to regular active smoking was performed. To assess the degree of inflammation in periodontal tissues we used marginally-papillary-alveolar index, periodontal index, the Green-Vermilyon index.

Results and Discussion. Dental examination of persons exposed to regular active smoking, revealed periodontal disease in 102 individuals (85.0\%), intact periodont - 18 persons (15.0\%). At the same time, investigation of 30 control individuals showed periodontal disease in 12 persons (40.0\%), clinically healthy periodontal tissue - in 18 persons (60.0\%). PMA index of individuals exposed to regular active smoking, treated as severe gingivitis and was significantly higher than data of the control group in 2.5 times. Average numerical values of periodontal index in patients exposed to regular active smoking answered moderate periodontitis and significantly were higher than data of the control group in 4 times. Oral hygiene status in $62 \%$ of those exposed to regular active smoking, was poor, $7 \%$ - very poor, $22 \%$ - satisfactory, $9 \%$ - good. Average numerical values of Green-Vermilyon index in smokers was significantly higher than data of the control group in 3.1 times.

Conclusions. Thus, smoking contributes to increasing of diffuse periodontal diseases and deepening of pathological process.

Key words: periodont; smoking; hygienic status; oral cavity.

Вступ. Сучасна медико-демографічна ситуація в Україні характеризується тим, що країна вступила в якісно новий етап свого розвитку депопуляцію. Уже 20-річна чисельність померлих перевищує чисельність народжених. За п'ять років кількість населення скоротилася на 1 млн 151. тис осіб [3]. Така ситуація відбувається на тлі прогресуючого поширення тютюнокуріння, а також інших згубних шкідливих звичок [2]. Куріння цигарок серед населення щороку зростає: у 90-х роках воно відмічалось у 2,6 \% непрацездатних осіб, у 2020 р. прогнозують його зростання до $19 \%$ осіб. У світі налічується близько 1,3 млрд людей, що курять [3, 4, 7], у країнах СНД - близько 29 \% дорослого населення, у країнах Європи - до 28 \%. Велика поширеність куріння серед чоловіків відмічається у Латвії, Естонії, Польщі, Молдові, Туреччині, в Україні. Найбільше курців серед чоловіків у Південній Кореї (68 \%), а серед жінок - у Данії (37 \%) [5]. Середньосвітове вживання тютюну становить 1650 цигарок на людину в рік [4].

Важливо відмітити, що населення України складає 0,85 \% від населення земної кулі, а 1,5 \% світової продукції тютюну використовується в Україні. За споживанням цигарок Україна посідає 17 місце у світі [7].

3 курінням пов’язують істотне підвищення ризику ряду захворювань органів і тканин порожнини рота, перш за все патології пародонта та онкологічних новоутворень порожнини рота [9]. Незважаючи на те, що більшість авторів провідну роль у виникненні запальних за- 
хворювань пародонта приділяє бактеріальній колонізації, деякі науковці припускають, що мікробна інвазія може бути лише пусковим механізмом у процесі руйнування тканин, які входять до складу пародонта [10]. Отже, вивчення впливу різних екзогенних та ендогенних факторів, у тому числі й тютюнового диму, на механізм локальної тканинної реакції є на сьогодні актуальною проблемою пародонтології.

Мета дослідження - вивчити поширеність, структуру та особливості клінічного перебігу захворювань тканин пародонта в осіб, схильних до регулярного активного куріння.

Матеріали і методи. Для реалізації поставленої мети проведено дослідження 120 відвідувачів, які проходили профілактичні огляди в поліклініці Збаразької центральної районної комунальної лікарні, схильних до регулярного активного куріння.

Критеріями включення пацієнтів у групу спостереження були: регулярне активне куріння (від 1 цигарки щодня і частіше); вік від 18 до 60 років.

Критеріями виключення хворих у групи були: вік менше 18 і більше 60 років; нерегулярне куріння (менше 1 цигарки на добу), куріння в минулому; тяжка серцева недостатність; хронічні захворювання внутрішніх органів у стадії загострення; системні захворювання сполучної тканини; злоякісні захворювання, відмова від участі в дослідженні. Контрольна група була представлена 30 практично здоровими особами (18 жінок і 12 чоловіків) у віці від 18 до 60 років, які ніколи не курили.

Обстеження тканин пародонта починали 3 огляду ясен. Запалення ясен, як один із основних симптомів захворювання пародонта, характеризується гіперемією, ціанозом, набряком, кровоточивістю, десквамацією епітелію.

Важливою клінічною ознакою пародонтиту $€$ пародонтальна кишеня, для вимірювання глибини якої використовували градуйований зонд. Глибина пародонтальної кишені відстань від шийки зуба (емалево-цементної межі) до дна кишені визначали біля кожного зуба окремо [1].

Для оцінки ступеня запального процесу в пародонті використовували папілярномаргінально-альвеолярний (РМА) індекс: слизову оболонку ясен верхньої та нижньої щелеп змащували розчином Шиллера-Писарєва. При цьому запалені ділянки ясен набува- ють коричневого забарвлення за рахунок присутності в них глікогену.

Оцінку індексу РМА проводили за такими критеріями: 0 - відсутність запалення; 1 - запалення тільки ясенного сосочка; 2 - запалення маргінальної частини ясен; 3 - запалення альвеолярної частини ясен.

РМА індекс $=($ сума балів $/ 3$ х число зубів $) x$ $100 \%$.

Інтерпретували результати наступним чином: індекс РМА до $30 \%$ - гінгівіт легкого ступеня; індекс РМА 31-60 \% - гінгівіт середнього ступеня; індекс РМА 61 \% і більше - гінгівіт тяжкого ступеня.

Пародонтальним індексом (ПI) користувались для виявлення розвинутих форм патології: 0 - відсутні ознаки запалення; 1 - легкий гінгівіт (часткове запалення ясен в ділянці зуба); 2 - гінгівіт навколо шийки зуба, однак ураження циркулярної зв'язки зуба немає; 4 оцінку проводили рентгенологічно; 6 - гінгівіт з утворенням пародонтальної кишені, зуб нерухомий. Не порушена жувальна функція зуба; 8 - виражена деструкція тканин пародонта із втратою жувальної функції. Зуб легко рухомий, зміщений.

Критерії оцінки ПІ визначали за формулою: сума оцінок біля кожного зуба/число зубів у досліджуваного.

ПІ оцінювали наступним чином: 0,1-1,0 пародонтит легкого ступеня; 1,5-4,0 - пародонтит середнього ступеня; 4,0-8,0 - пародонтит тяжкого ступеня.

Важливе значення в етіології та перебігу захворювань пародонта має гігієнічний стан порожнини рота, який характеризували за індексом Гріна-Вермільйона, що передбачає визначення зубних відкладень у ділянці поряд розташованих зубів нижньої та верхньої щелеп з вестибулярного та орального боків. Індекс вираховували наступним чином: 0 - відсутність відкладень; 1 - відкладення вкривають менше 1/3 поверхні зуба; 2 - відкладення вкривають від 1/3 до 2/3 поверхні зуба; 3 - відкладення вкривають більше 2/3 поверхні зуба.

При нерівномірному розташуванні відкладень оцінювали ту поверхню зуба, на якій було більше відкладень.

Розрахунок проводили за формулою: сума оцінок біля кожного зуба/6.

Статистичну обробку цифрових даних здійснювали за допомогою програмного забезпечення Excel (Microsoft, CША) та STATISTICA 6.0. (Statsoft, США) з використанням не- 
параметричних методів оцінки одержаних даних. Для всіх показників розраховували значення середньої арифметичної вибірки (M), iï дисперсії і помилки середньої (m). Достовірність різниці значень між незалежними кількісними величинами визначали за допомогою критерію Вілкоксона - Манна Уїні.

Результати досліджень та їх обговорення. Стоматологічне обстеження осіб, схильних до регулярного активного куріння, виявило захворювання пародонта у 102 осіб (85,0 \%), інтактний пародонт - у 18 осіб (15,0 \%) (табл. 1). Разом 3 тим, обстеження 30 осіб контрольної групи виявило захворювання пародонта у 12 осіб (40,0 \%), клінічно здорові тканини пародонта - у 18 осіб (60,0 \%).

Поширеність основних нозологічних форм захворювань пародонта у групах спостереження графічно унаочнено на рисунку.

таблиия 1. Розповсюдженість та структура захворювань пародонта в осіб, схильних до регулярного активного куріння $(\mathrm{M} \pm \mathrm{m})$

\begin{tabular}{|l|c|c|c|c|}
\hline \multirow{2}{*}{ Стан пародонта } & \multicolumn{2}{|c|}{ Дослідна група } & \multicolumn{2}{c|}{ Контрольна група } \\
\cline { 2 - 5 } & абс. & $\%$ & абс. & $60,0 \pm 4,81$ \\
\hline $\begin{array}{l}\text { Клінічно здорові тканини } \\
\text { пародонта }\end{array}$ & 18 & $\begin{array}{c}15,0 \pm 1,47 \\
\mathrm{p}<0,05\end{array}$ & 18 & $16,7 \pm 2,05$ \\
\hline Гінгівіт & 29 & $\begin{array}{c}24,2 \pm 2,57 \\
\mathrm{p}<0,05\end{array}$ & 5 & $13,3 \pm 1,80$ \\
\hline Генералізований пародонтит & 34 & $\begin{array}{c}28,3 \pm 2,09 \\
\mathrm{p}<0,05\end{array}$ & 4 & $6,7 \pm 1,10$ \\
І ступеня & & $\begin{array}{c}25,8 \pm 2,68 \\
\mathrm{p}<0,05\end{array}$ & 2 & $3,3 \pm 0,47$ \\
\hline Генералізований пародонтит & 31 & $\begin{array}{c}6,7 \pm 1,02 \\
\mathrm{p}<0,05\end{array}$ & 1 & \\
\hline ІІ ступеня & 8 & & & \\
\hline Генералізований пародонтит & & & & \\
ІІІ ступеня & & & & \\
\hline
\end{tabular}

Примітка. р - вірогідність відмінностей між контрольною і дослідною групами.

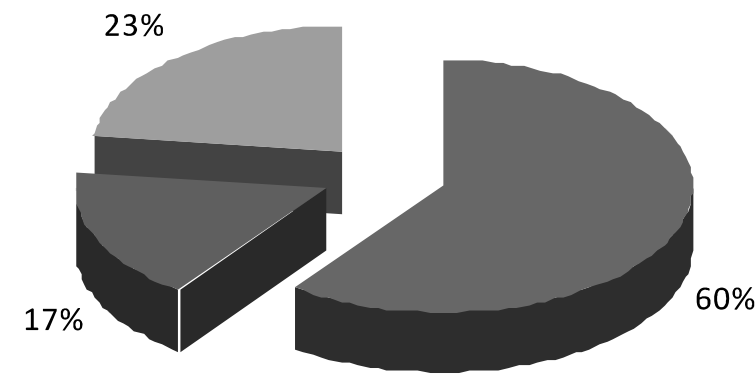

Контрольна група

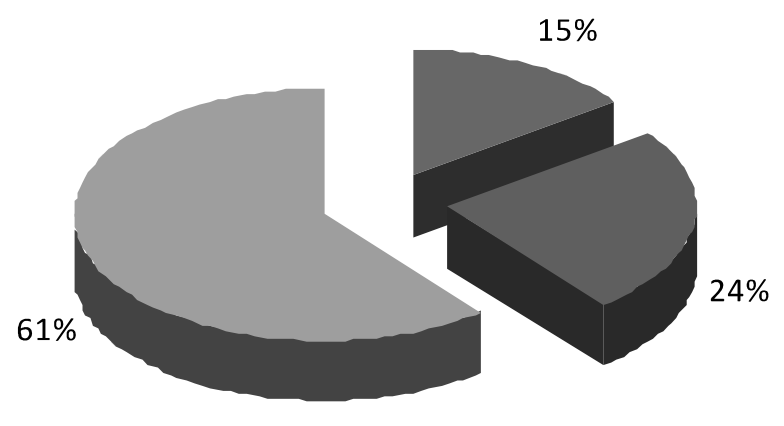

вдоровий пародонт, \%

гінгівіт, \%

$$
\begin{aligned}
& \text { генералізований } \\
& \text { пародонтит, \% }
\end{aligned}
$$


Таким чином, у курців виявлено вищу поширеність та інтенсивність захворювань пародонта, порівняно з особами, які не курять.

Пародонтальні кишені глибиною більше 3 мм спостерігалися у 105 осіб (87,5 \%), схиль- них до регулярного активного куріння, та у 9 осіб (30 \%) контрольної групи. Для визначення інтенсивності запальних процесів у тканинах пародонта були проаналізовані дані окремих параклінічних індексів (табл. 2).

Таблищя 2. Динаміка індексів запалення пародонта в осіб, схильних до регулярного активного куріння $(\mathrm{M} \pm \mathrm{m})$

\begin{tabular}{|l|c|c|}
\hline \multicolumn{1}{|c|}{ Індекс } & Дослідна група & Контрольна група \\
\hline Індекс РМА, \% & $71,84 \pm 3,15$ & $28,44 \pm 2,01$ \\
& $\mathrm{p}<0,05$ & $0,82 \pm 0,09$ \\
\hline Пародонтальний індекс & $3,26 \pm 0,57$ & \\
& $\mathrm{p}<0,05$ & $0,7 \pm 0,04$ \\
\hline Індекс Гріна - Вермільйона & $2,2 \pm 0,12$ & \\
& $\mathrm{p}<0,05$ & \\
\hline
\end{tabular}

Примітка. p - вірогідність відмінностей між контрольною і дослідною групами.

В осіб, схильних до регулярного активного куріння, середні значення індексу РМА трактували як гінгівіт тяжкого ступеня та достовірно перевищували аналогічні дані групи контролю у 2,5 раза. Середні цифрові значення пародонтального індексу в осіб, схильних до регулярного активного куріння, відповідали пародонтиту середнього ступеня та достовірно перевищували аналогічні дані групи контролю у 4 рази. Стан гігієни ротової порожнини у 62 \% осіб, схильних до регулярного активного куріння, відповідав поганому гігієнічному стану, в 7 \% - дуже поганому, 22 \% - задовільному, $9 \%$ - доброму. Середні значення індексу ГрінаВермільйона у курців достовірно перевищували аналогічні дані групи контролю у 3,1 раза.

Подібні результати отримані й у роботах інших авторів. Так, О. О. Янушевич та співав. у молодих осіб з нікотиновою залежністю виявили значне зменшення мікроциркуляції у тканинах пародонта, що супроводжувалося більш тяжким ступенем ураження його тканин [6].

Тютюнокуріння сприяє розвитку захворювань парадонта за рахунок декількох

\section{Список літератури}

1. Грудянов А. И. Заболевания пародонта / А. И. Грудянов. - М. : Медицинское информационное агентство, 2009. - 336 с.

2. Ещенко К. Н. Сердечно-сосудистая система и курение / К. Н. Ещенко, А. В. Жадан, Н. Ф. Шустваль // Ліки України. - 2013. - Вип. 4. - С. 12-17.

3. Кваша Е. А. Значимость факторов риска для смертности мужчин (проспективное эпидемиологическое исследование) / Е. А. Кваша // Український кардіологічний журнал. - 2008. - № 2. - С. 83-88. механізмів. Органи і тканини порожнини рота є місцем первинного контакту організму курця 3 токсинами і канцерогенами, що входять до складу тютюнового диму (більш як 4000 різних токсинів, у тому числі близько 40 канцерогенів та мінімум 12 речовин, які сприяють виникненню раку). Тютюновий дим пригнічує механізми імунного захисту - стійке зниження фагоцитарної функції. Вплив нікотину на мікроциркуляторне русло проявляеться в порушенні гемодинаміки у м’яких тканинах порожнини рота, зумовлюючи погіршення трофіки ясен і зниження іiі резистентності до інфекції. Розвивається атрофія ацинарних відділів малих слинних залоз і виникають інші морфологічні зміни, характерні для прогресуючого хронічного сіалоденіту. Знижується здатність фібробластів до синтезу колагену, що призводить до руйнування зубоясенного прикріплення і подальшої резорбції альвеолярної кістки [8, 9].

Висновки. Куріння сприяє збільшенню дифузних захворювань пародонта та поглибленню патологічного процесу.

4. Контроль над тютюном в Україні. Другий Національний звіт. - К. : МОЗ України, ДУ «Український інститут стратегічних досліджень МО3 України», 2014. - 128 c.

5. Красовський К. С. Наслідки глобальної тютюнової епідемії / К. С. Красовський // СЕС. Профілактична медицина. - 2009. - № 4. - С. 72-74.

6. Методы профилактики хронического пародонтита при никотиновой зависимости в молодом возрасте с точки зрения гемодинамических нарушений в 
пародонте / О. О. Янушевич, А. Л. Верткин, А. В. Наумов, В. А. Вышиванюк // Современная стоматология. - 2012. - № 2. - С. 8-14.

7. Пікас О. Б. Куріння цигарок серед населення та його роль у розвитку захворювань / О. Б. Пікас // Вісник проблем біології і медицини. - 2016. - Вип. 1, т. 1 (126). - С. 48-52.

8. Токмакова С. И. Влияние табакокурения на слизистую оболочку полости рта / С. И. Токмакова, Ю. В. Луницина // Забайкальский медицинский вестник. - 2012. - № 1. - С. 124-130.

\section{REFERENCES}

1. Grudyanov, A.I. (2009). Zabolevaniya parodonta [Periodontal diseases]. Moscow: Meditsinskoye informatsionnoye agentstvo [in Russian].

2. Eshchenko, K.N., Zhadan A.V. \& Shustval, N.F. (2013). Serdechno-sosudistaia sistema i kurenie [Cardiovascular system and smoking]. Liky Ukrainy - Medicines of Ukraine, 4, 12-17 [in Russian].

3. Kvasha, E.A. (2008). Znachimost faktorov riska dlia smertnosti muzhchin (prospektivnoe epidemiologicheskoe issledovanie) [Importance of risk factors for male mortality (prospective epidemiological study)]. Ukrainskyi kardiolohichnyi zhurnal - Ukrainian Journal of Cardiology, 2, 83-88 [in Russian].

4. Kontrol nad tiutiunom v Ukraini. Druhyi Natsionalnyi zvit. [Tobacco Control in Ukraine. Second National Report]. (2014). Kyiv: MOZ Ukrainy, DU «Ukrainskyi instytut stratehichnykh doslidzhen MOZ Ukrainy» [in Ukrainian].

5. Krasovskyi, K.S. (2009). Naslidky hlobalnoi tiutiunovoi epidemii [The effects of the global tobacco epidemic]. SES. Profilaktychna medytsyna - SES. Preventive Medicine, 4, 72-74 [in Ukrainian].

6. Yanushevich, O.O., Vertkin, A.L., Naumov, A.V., Vyshivanyuk V.A. (2012) Metody profilaktiki khronicheskogo parodontita pri nikotinovoy zavisimosti $\mathrm{v}$ molodom
9. Шепилев В. В. Профилактика заболеваний полости рта, связанных с курением / В. В. Шепилев, С. М. Ворожбит, Т. В. Камина // Стоматология. -2007.-№ 9.C. 20-22.

10. Gadhia K. Management of periodontal disease in general dental practice // K. Gadhia, N. Karir // Dent. Update. - 2010. - Vol. 37(5). - P. 310-320.

vozraste s tochki zreniya gemodinamicheskikh narusheniy $\mathrm{v}$ parodonte [Methods of chronic periodontitis preventing in nicotine dependence at a young age in terms of hemodynamic disorders in the periodontium]. Sovremennaya Stomatologiya - Modern Dentistry, 2, 8-14 [in Russian].

7. Pikas, O.B. (2016). Kurinnia tsyharok sered naselennia ta yoho rol u rozvytku zakhvoriuvan [Smoking cigarettes among population and its role in development of diseases]. Visnyk problem biolohii i medytsyny - Journal of Medical and Biological Problems, 1, (126), 48-52 [ in Ukrainian].

8. Tokmakova, S.I. \& Lunicina, Yu.V. (2012). Vliyaniye tabakokureniya na slizistuyu obolochku polosti rta [Effect of tobacco smoking on the mucosa of the oral cavity]. Zabaykalskiy meditsinskiy vestnik - The Transbaikal Medical Gazette, 1, 124-130 [in Russian].

9. Shepilev, V.V., Vorozhbit, S.M., Kamina, T.V. (2007). Profilaktika zabolevaniy polosti rta, svyazannykh s kureniyem [Prevention of oral diseases associated with smoking]. Stomatologiya - Dentistry, 9, 20-22 [in Russian].

10. Gadhia, K, Karir, N. (2010). Management of periodontal disease in general dental practice. Dent. Update, 37 (5), 310-320. 